the new law. ${ }^{46}$ Nor would the argument that it is not the true function of the judiciary to set down law for the future ${ }^{47}$ seem to have any relevancy in this situation, assuming it has any validity at all, since the job of interpreting the due process clause by its nature belongs to the courts and cannot be an encroachment on the function of the legislature.

${ }^{48}$ This procedure was followed in Shioutakon v. District of Columbia, 236 F.2d 666, 670 (App. D.C., 1956) ; Durham v. United States, 214 F.2d 862, 874 (App. D.C., 1954) ; Steward v. United States, 214 F.2d 879, 882 (App. D.C., 1954); cf. Addison v. Holly Hill Co., 322 U.S. 607, 619-22 (1944).

${ }^{47}$ Consult Moschzisker, Stare Decisis In Courts Of Last Resort, 37 Harv. L. Rev. 409, 426-27 (1924).

\title{
JUDGMENTS OF ACQUITTAL: THE RIGHT TO A NON-JURY TRIAL
}

\section{I}

Judgments of acquittal ${ }^{1}$ in criminal cases have a relatively short history. Not until $1850,{ }^{2}$ and in some instances even later, ${ }^{3}$ was the notion that the jury is properly the trier of issues of law as well as fact finally discarded and the civil practice of demurrer to the evidence carried over into the criminal courts. ${ }^{4}$ Today, by reason of general recognition of the acquittal procedure, ${ }^{5}$ controversy has shifted to the circumstances which require the trial judge to take a case from the jury. Surprisingly enough, at least three distinct tests have been developed. Deserving of particular interest is the position of the Court of Appeals for the Second Circuit, recently reaffirmed in United States v. Masiello, ${ }^{6}$ that "the standard of evidence necessary to send a case to the jury is the same in both civil and criminal cases. . .."

${ }^{1}$ The term directed verdict has been replaced in federal criminal cases by the phrase "motion for judgment of acquittal." 62 Stat. 869 (1948), 18 U.S.C.A. $\$ 29$ (a) (1951). This change in nomenclature did not modify the nature of the motion or enlarge the scope of the matters to be considered in ruling on it, Note to 18 U.S.C.A. $\$ 29$ (a) (1951), and will be followed herein.

${ }^{2}$ Parks v. Ross, 11 How. (U.S.) 361 (1850) (trial judge may give the jury an imperative instruction to find for the accused); see United States v. Battiste, 24 Fed.Cas. 1042 (C.C. Mass., 1835).

${ }^{3}$ Connecticut, for example, as late as 1894 had a statute which forbade the trial judge from directing the return of any particular verdict. See State v. Fetterer, 65 Conn. 287, 32 Atl. 394 (1894).

'Consult Blume, Origin and Development of the Directed Verdict, 48 Mich. L. Rev. 555 (1950), for a detailed historical analysis.

${ }^{5}$ Only Louisiana and North Dakota do not permit directed verdicts in criminal cases. State v. Broussard, 217 La. 90, 46 So.2d 48 (1950) ; State v. Pusch, 77 N.D. 860, 46 N.W.2d 508 (1950).

235 F.2d 279 (C.A. 2d, 1956) (alternative holding by divided court), cert. denied 352 U.S. 882 (1956).

${ }^{7}$ United States v. Feinberg, 140 F.2d 592, 594 (C.A. 2d, 1944). 
Most courts state that the criminal defendant is entitled to an acquittal if reasonable men could not conclude on the evidence taken in the light most favorable to the prosecution ${ }^{8}$ that guilt has been proved beyond a reasonable doubt. ${ }^{9}$ Thus, it is something of an innovation to suggest that an acquittal is not proper where reasonable men could find guilt has been proved merely by a preponderance of the evidence. ${ }^{10} \mathrm{In}$ fact, apart from the Second Circuit, no jurisdiction follows, or has even suggested the possibility of following, this "civil" test. Thus, since the civil test would appear to be lacking in historical justification, cogent reasons must be sought upon which to base its adoption.

Two principal arguments may be urged in support of the civil test. It has been contended that the difference between evidence which merely preponderates and evidence which excludes all reasonable doubt is so ephemeral as to eliminate the possibility of workable application to concrete situations. ${ }^{11}$

${ }^{8}$ E.g., United States v. Horton, 180 F.2d 427, 428 (C.A. 7th, 1950): The issues raised by the motion for judgment of acquittal "require a statement of the evidence most favorable to the government, and in making such statement we shall ignore the testimony of the defendant."

${ }^{8}$ Federal courts (only the most recent in each circuit are cited) : Crockett v. United States, 234 F.2d 560 (C.A. 5th, 1956) ; Freidus v. United States, 223 F.2d 598 (App. D.C., 1955); Remmer v. United States, 205 F.2d 277 (C.A. 9th, 1953) ; United States v. Horton, 180 F.2d 427 (C.A. 7th, 1950); Parnell v. United States, 64 F.2d 324 (C.A. 10th, 1932); Chicco v. United States, 284 Fed. 434 (C.A. 4th, 1922) ; United States v. Ginn, 124 F.Supp. 658 (E.D. Pa., 1954), rev'd on other grounds, 222 F.2d 289 (C.A. 3d, 1955). Of the remaining circuits, the first has not passed on the question; the second (see note 10 infra), and the sixth and eighth (see note 18 infra) follow different rules.

State courts: Winn v. State, 79 So.2d 75 (Ala. App., 1954) ; Hardin v. State, 225 Ark. 602, 284 S.W.2d 111 (1955); People v. Huizenga, 34 Cal.2d 669, 213 P.2d 710 (1950); State v. Torello, 100 Conn. 637, 124 Atl. 375 (1924); State v. Biter, 49 Del. 503, 119 A.2d 894 (1955); Albritton v. State, 132 Fla. 801, 182 So. 286 (1938); State v. McCarty, 47 Idaho 117, 272 Pac. 695 (1928) ; People v. Clark, 1 Ill.App.2d 250, 117 N.E.2d 421 (1954) ; State v. Torphy, 217 Ind. 383, 28 N.E.2d 70 (1940); State v. Miskell, — Iowa -, 73 N.W.2d 36 (1955); State v. Gibbs, 105 Kan. 52, 181 Pac. 569 (1919) ; State v. Allen, - Me. -, 121 A.2d 342 (1956); Yanch v. State, 201 Md. 296, 93 A.2d 749 (1953); McLendon v. State, 187 Miss. 247, 191 So. 821 (1939), citing for authority, Justice v. State, 170 Miss. 96, 154 So. 265 (1934) ; State v. Perez, 126 Mont. 15, 243 P.2d 309 (1952); Onstott v. State, 156 Neb. 55, 54 N.W.2d 380 (1952); State v. LeNoir, 97 N.H. 462, 92 A.2d 159 (1952); State v. Rogers, 19 N.J. 218, 116 A.2d 37 (1955); Kilpatrick v. State, 58 N.M. 88, 265 P.2d 978 (1953); People v. Hoffner, 208 N.Y. Misc. 117, 129 N.Y.S.2d 833 (1952), citing People v. Ledwon, 153 N.Y. 10, 46 N.E. 1046 (1897) ; State v. Hovis, 233 N.C. 359, 64 S.E.2d 564 (1951); City of Columbus v. Charlton, 84 Ohio App. 401, 87 N.E.2d 380 (1949); Clark v. State, 95 Okla. Cr. 117, 239 P.2d 797 (1952); State v. Molitor, 205 Ore. 698, 289 P.2d 1090 (1955); Commonwealth v. Beati and Burrell, $86 \mathrm{~Pa}$. Sup. 567 (1925); State v. Lorenzo, 72 R.I. 175, 48 A.2d 407 (1946); State v. Boone, 228 S.C. 438, 90 S.E.2d 640 (1955); State v. Bates, - S.D. - 71 N.W.2d 641 (1955); Liakas v. State, - Tenn. -, 286 S.W.2d 856 (1956); State v. Penderville, 2 Utah 2d 281, 272 P.2d 195 (1954); State v. Hart, - Vt. 一, 117 A.2d 387 (1955); State v. McHenry, 93 W.Va. 396, 117 S.E. 143 (1923).

${ }^{10}$ United States v. Masiello, 235 F.2d 279 (C.A. 2d, 1956), cert. denied 352 U.S. 882 (1956); United States v. Castro, 228 F.2d 807 (C.A. 2d, 1956); United States v. Feinberg, 140 F.2d 592 (C.A. 2d, 1944).

${ }^{11}$ United States v. Feinberg, 140 F.2d 592, 594 (C.A. 2d, 1944). 
However, it does not follow that because there may be difficulty in distinguishing between these two degrees of proof, the lesser should be chosen as the standard for determining acquittals. Equally reasonable is an acceptance of the more stringent majority rule--beyond a reasonable doubt-unless it be assumed that judges in criminal cases are more familiar with civil rather than criminal law concepts. In any event, the Second Circuit has recognized that there is a difference between "preponderance" and "beyond a reasonable doubt."12 Moreover, it requires juries in civil cases to apply the former and juries in criminal cases to apply the latter, thus lending credence to the view that the trial judge is probably qualified to draw a similar distinction. Finally, if the criminal jury is deemed competent to apply the reasonable doubt standard, surely the trial judge is also at least as capable of using it in an understanding manner.

The civil test may also be defended as a legitimate response to the problems of proof in convicting the "shrewder criminal."13 Thus, for example, in tax evasion cases $^{14}$ where the prosecution is forced to rely on the net worth method of establishing guilt because the taxpayer has hidden his records, or in conspiracy cases $^{15}$ where only the "veriest bunglars" make their joint enterprise explicit, it would seem fair to allow the case to go to the jury and rely on lay ability to be sufficiently discriminating to avoid the rendition of unjustified verdicts. However, the Second Circuit does not purport to limit its civil test merely to cases involving indirect or circumstantial evidence. ${ }^{16}$ Rather, it would increase the risk of unreasonable verdicts for all defendants regardless of the nature of the offense charged and the type of proof available. This historically unwarranted boon to the prosecution thus goes far beyond the justification advanced. Furthermore, application of the civil test to all cases does not seem required by the difficulty in drawing a line between those where it may properly be applied and all other cases. It is clear that such a distinction is possible and in fact often implicitly made today by the trial judge in ruling on a motion for judgment of acquittal. ${ }^{17}$ Finally, it will be noted that the civil test is probably objectionable even though limited to cases involving circumstantial evidence. If so limited, the result will be different treatment in terms of fundamental procedure for defendants charged with the same or similar crimes, depending largely on the nature of the proof adduced. So stated, such a result seems improbable so long as individual liberty is valued

${ }^{12}$ Ibid., at 594.

${ }^{13}$ See United States v. Valenti, 134 F.2d 362, 364 (C.A. 2d, 1943).

${ }^{16}$ E.g., United States v. Riganto, 121 F.Supp. 158 (E.D. Va., 1954).

${ }^{15}$ E.g., United States v. Valenti, 134 F.2d 362, 364 (C.A. 2d, 1943).

${ }^{18}$ Consult cases cited note 10 supra.

${ }^{17}$ See United States v. Riganto, 121 F.Supp. 158 (E.D. Va., 1954). The suggestion is that the trial judge will consider the factors discussed in the text, albeit improper, in his acquittal determination. 
and guilt thought to depend upon something more than whim or chance. It may thus be concluded that the Second Circuit's view of the standard to be used in determining the propriety of an acquittal is erroneous both as a matter of history and as a question of reason.

II

In those jurisdictions which reject the civil test, there is almost complete acceptance of the majority view that a motion for judgment of acquittal must be denied if, on the evidence taken most favorably to the prosecution, $a$ conclusion of guilt beyond a reasonable doubt is reasonable (although the opposite conclusion be equally reasonable) ${ }^{18}$ Nevertheless, a small and waning ${ }^{19}$ number of courts have suggested that submission of a case to the jury is improper unless the only conclusion which the evidence permits is that of guilt beyond a reasonable doubt. ${ }^{20}$

Perhaps the leading formulation of this "strict" test is that stated in Isbell v. United States: ${ }^{21}$

Unless there is substantial evidence of facts which exclude every other hypothesis but that of guilt it is the duty of the trial judge to instruct the jury to return a verdict for the accused....

On its face this oft-quoted statement expresses what is generally recognized as a proper instruction to the jury in cases involving circumstantial evidence. ${ }^{22}$ Nevertheless, at one time or another the strict test has been held applicable to rulings on a motion for judgment of acquittal by a majority of the federal circuits, ${ }^{23}$ including the Second Circuit, ${ }^{24}$ and several states as well. ${ }^{25}$ Moreover, many of those courts which have accepted the strict test appear to view

${ }^{18}$ Consult authorities cited note 9 supra.

${ }^{10}$ Compare cases cited note 20 infra with those in notes $23-25$ infra.

${ }^{20}$ Jurisdictions presently following this rule in one form or another: Isbell v. United States, 227 Fed. 788 (C.A. 8th, 1915) (but compare United States v. Brennan, 137 F.Supp. 888 [D. Minn., 1956]) ; W. F. Corbin \& Co. v. United States, 181 Fed. 296 (C.A. 6th, 1910) ; State v. Kolander, 236 Minn. 209, 52 N.W.2d 458 (1952); Burgin.v. Commonwealth, 311 Ky. 728, 225 S.W.2d 293 (1949).

${ }^{*} 227$ Fed. 788, 792 (C.A. 8th, 1915).

22E.g., California Jury Instructions Criminal No. 26 (1946) ; McCarty, Illinois Instructions to Juries $\$ 557$ (1932).

${ }^{23}$ Hammond v. United States, 127 F.2d 752 (App. D.C., 1942) ; Moore v. United States, 56 F.2d 794 (C.A. 10th, 1932); Nosowitz v. United States, 282 Fed. 575 (C.A. 2d, 1922); Isbell v. United States, 227 Fed. 788 (C.A. 8th, 1915) ; W. F. Corbin \& Co. v. United States, 181 Fed. 296 (C.A. 6th, 1910); United States v. Hart, 78 Fed. 868 (E.D. Pa., 1897); United States v. McKenzie, 35 Fed. 826 (S.D. Cal., 1887).

${ }^{24}$ Romano v. United States, 9 F.2d 522 (C.A. 2d, 1925) ; Nosowitz v. United States, 282 Fed. 575 (C.A. 2d, 1922).

${ }^{25}$ State v. Kolander, 236 Minn. 209, 52 N.W.2d 458 (1952); Burgin v. Commonwealth, 311 Ky. 728, 228 S.W.2d 293 (1949); People v. Ward, 105 Cal. 335, 38 Pac. 945 (1894); People v. Bennett, 49 N.Y. 137 (1872). 
it as the sole standard applicable to a determination of the propriety of an acquittal, ${ }^{26}$ and do not limit it to being merely one of the aids by which the strength of inferences may be weighed in cases involving circumstantial evidence. ${ }^{27}$ It is thus clear that an accurate statement of the strict test should go beyond the narrow Isbell formulation: the trial judge must grant an acquittal when a conclusion of guilt beyond a reasonable doubt is not the only reasonable conclusion possible..$^{28}$

Two principal criticisms have been leveled at the strict test. First, that it fails to distinguish "between the tests applicable to a motion for a directed verdict and the tests by which a jury must determine its verdict." ${ }^{20}$ There is considerable merit to this objection, for one reading of the early cases suggests that their adoption of the strict test for acquittals was motivated by rules enunciated in decisions involving instructions to the jury. ${ }^{30}$ Nevertheless, there would appear to be no reason, apart from questions of precedent and policy, why the judge and jury should not follow a similar standard. Furthermore, under present law the scope of the strict test has expanded well beyond that of its jury counterpart and may therefore be said to be something quite distinct. ${ }^{31}$

It has also been contended that the strict test is erroneous because it is based on a confused notion of what constitutes a reasonable doubt. ${ }^{32}$ Merely because reasonable men might disagree on a conclusion of guilt, so the argument runs, does not mean that there is a reasonable doubt. The validity of this argument must be conceded. Nevertheless, it may be answered that the strict test does not purport to rest on the proposition that when reasonable

${ }^{20}$ E.g., Moore v. United States, 56 F.2d 794 (C.A. 10th, 1932) ; Partson v. United States, 20 F.2d 127 (C.A. 8th, 1927).

${ }^{27}$ E.g., Leslie v. United States, 43 F.2d 288 (C.A. 10th, 1930).

It is unclear how courts using the strict test only in cases involving circumstantial evidence would handle a case involving direct and circumstantial evidence. In fact, this diffculty points to the adoption of a single test across the board and casts doubt upon any purported limitation of a rule to one type of evidence.

${ }^{23}$ In United States v. Cole, 90 F.Supp. 147, 154 (S.D. Cal., 1950), the court although adopting the majority test described the strict test in these terms: "[C]ourts are not agreed as to the criteria which determine whether evidence is or is not sufficient to go to the jury. Some of them have held that the doctrine of reasonable doubt is so binding on the trial court that if the evidence is such that a reasonable doubt could arise in the minds of the jurors, the duty of the court is to take the case from the jury."

Curley v. United States, 160 F.2d 229, 235 (App. D.C., 1947), cert. denied 331 U.S. 837 (1947).

${ }^{30}$ Consult, e.g., Hart v. United States, 84 Fed. 799 (C.A. 3d, 1898).

${ }^{31}$ Consult text at notes 26 and 28 supra.

It will be noted that insofar as the strict test is deemed to extend beyond cases involving circumstantial evidence, the strict test does extend beyond the instructions given to the jury. Compare note 22 with note 28 supra.

${ }^{32}$ Curley v. United States, 160 F.2d 229 (App. D.C., 1947), cert. denied 331 U.S. 827 (1947). 
men may disagree, there is a reasonable doubt. Instead, under the strict test the fact that such disagreement is possible is taken to indicate that there is some degree of speculation in sending such a case to the jury. In other words, if a reasonable jury could properly find innocence on a given set of facts, it is wrong to refuse to acquit solely because another reasonable jury might properly reach a conclusion of guilt on the same facts. Admittedly, the strict test thus expands the role of the trial judge from merely eliminating the possibility of unreasonable verdicts of guilt (majority view) to ensuring that when a verdict of guilt is rendered, it is the only reasonable conclusion possible. Whether this is sound judicial administration remains to be discussed.

Taken as a whole, conventional considerations seem to point to a preference of the strict test over the majority rule. The former, since it lays down a higher standard of proof which the prosecution must meet before its case can go to the jury, will decrease the possibility of erroneous verdicts of guilt, ${ }^{33}$ discourage the bringing of prosecutions on tenuous evidence, and lessen the chance that the trial judge will depart from his role as an impartial arbiter in order to compensate for shortcomings of proof. Moreover, it is probable that the strict test will be more carefully and faithfully applied than the majority rule because the likelihood of shifting responsibility to the jury is decreased when the trial judge, in denying an acquittal, must find that guilt is the only reasonable conclusion to be drawn and not merely $a$ reasonable conclusion. On the other hand, it would seem clear that a given determination under the majority rule will be less subject to appellate reversal than one under the strict test, since the majority test is more easily satisfied. It must also be recognized that the strict test may operate as a windfall to the criminal, impose undue burdens on prosecutors and investigative agencies, and constitute the jury a "rubber stamp" if it finds guilt or brand it as incorrect if it concludes innocence (unless the jury be deemed to have taken a different view of the facts than the trial judge).

Assumptions concerning the nature and functioning of the jury system are also relevant. If the jury does exactly what it is supposed to do, unaffected by non-logical considerations, the necessity of an acquittal procedure is obviated and, in any event, application of either the strict or the majority test will in most instances produce the same final result. ${ }^{34}$ Nor are these conclusions

${ }^{33}$ Consult text at 567 infra.

${ }^{34}$ Assuming the jury takes the facts in the light most favorable to the prosecution, as does the court, different judgments may result only in a case involving direct evidence where the conclusions of guilt beyond a reasonable doubt and innocence are equally reasonable. In such circumstances, the strict test would require an acquittal and the majority rule would permit the case to go to the jury who might find guilt. The strict test as so applied may be defended by noting that if on the evidence taken most favorably to the prosecution, guilt has not been shown to be more than $a$ reasonable conclusion, then a jury verdict of guilt is probably in error (for the jury might not take the same view of the evidence) and in any event speculative.

If, however, the case involves circumstantial evidence, or direct evidence where only one 
altered if the jury is in reality a sub rosa dispenser of justice, erring if at all in favor of the accused, for under this assumption the only difference would be defendant-prone verdicts, something beyond the reach of an acquittal procedure. But if the jury be assumed to be prosecution-prone, a group which is all too easily influenced to convict, then the strict test would appear more desirable than the majority rule if only for the reason that it will more significantly diminish the possibility of such jury behavior by removing the opportunity therefor in a greater number of cases. This assumption, furthermore, is one of the historical bases of the acquittal practice and runs throughout criminal practice, as, for example, many exclusionary rules of evidence. Which of the foregoing assumptions is empirically correct is not, however, verifiable at this time. It would thus seem wise to err on the side of mercy and follow the strict test.

In conclusion, it should be noted that the differences between the civil, majority and strict tests for weighing the evidence on a motion for judgment of acquittal are to some extent merely a matter of phraseology and of no practical import. Yet the standard chosen will at least indicate a mode of approach and as such will be crucial in many cases. Thus, the existence of three different standards would seem prima facie undesirable, for not all can be equally correct. Within the federal system, where each of these three tests is advocated by at least one circuit, it may be anticipated that the matter will soon be put to rest by the Supreme Court. ${ }^{35}$ At such time, it is to be hoped that the solution is fully in accord with enlightened criminal procedurewhich is herein submitted to require adoption of the strict test.

reasonable conclusion is possible, both tests will reach the same result. In the former situation, since the jury is in effect instructed under the strict test they will find innocence on a case sent to them under the majority rule, in which event there can be no difference. In the latter situation, the jury is presumably not instructed under the strict test, but if the one possible reasonable conclusion is only guilt (or only innocence), it is obvious that both tests will come out the same.

s Although no case is now pending, it may be inferred from a recent statement by Mr. Justice Harlan in Stickel v. United States, 76 S.Ct. 1067 (1956), that the Court will probably review federal acquittal procedure when the issue is presented in a proper case.

\section{LANDLORD'S DUTY TO MITIGATE DAMAGES UPON TENANT'S DEFAULT}

In Gruman v. Investors Diversified Services, Inc., ${ }^{1}$ the Supreme Court of Minnesota held that a landlord could arbitrarily refuse to consent to a sublease to a suitable subtenant secured by the tenant in an attempt to mitigate damages on a defaulted lease. The tenant had agreed not to "assign this lease nor underlet said premises, or any part thereof, without the consent of the

${ }^{2} 247$ Minn. 502, 78 N.W.2d 377 (1956). 